\title{
The Application of Quantum Teaching to Improve Students' Learning Outcomes Online at SD Negeri 1 Mewek Purbalingga During The Pandemic
}

\section{Dini Setyaningrum}

SD Negeri 1 Mewek

dinisetyaningrumdini@gmail.com

\section{Article History}

received 3/12/2020

\begin{abstract}
The purpose of this research was to improve student learning outcomes online through the application of the Quantum Teaching-Learning model at SD Negeri 1 Mewek, Kalimanah, Purbalingga. This type of research is called collaborative Classroom Action Research. The research took place in two cycles of action. Each cycle consisted of planning, implementing, observing, and reflecting activities. After the action research with the Quantum Teaching learning model in the first cycle, the average value of learning outcomes increased to 79, and students who achieved KKM were $76 \%$ of 17 students, while in the second cycle it increased to 82 and students who achieved KKM were 94\% of 17 students. In addition, the application of Quantum Teaching in learning can also encourage students to be active physically, mentally, and socially.
\end{abstract}

Keywords: learning outcomes, quantum teaching, class students

\begin{abstract}
Abstrak
Penelitian ini bertujuan untuk mendeskripsikan cara meningkatan hasil belajar siswa secara daring melalui penerapan model pembelajaran Quantum Teaching di SD Negeri 1 Mewek, Kalimanah, Purbalingga. Jenis Penelitian ini adalah Penelitian Tindakan Kelas (PTK) kolaboratif. Penelitian berlangsung dalam dua siklus tindakan. Setiap siklus terdiri dari kegiatan perencanaan, pelaksanaan, pengamatan (observasi) dan refleksi. Setelah dilakukan penelitian tindakan dengan model pembelajaran Quantum Teaching pada siklus pertama, nilai rata-rata hasil belajar meningkat menjadi 79 dan siswa yang mencapai KKM sebesar $76 \%$ dari 17 siswa, sedangkan pada siklus kedua meningkat menjadi 82 dan siswa yang mencapai KKM sebesar 94\% dari 17 siswa. Selain itu, penerapan Quantum Teaching dalam pembelajaran juga dapat mengaktifkan siswa secara fisik, mental, dan sosial.
\end{abstract}

Kata kunci: hasil belajar, quantum teaching, siswa kelas

Social, Humanities, and Education Studies (SHEs): Conference Series https://jurnal.uns.ac.id/shes

p-ISSN 2620-9284

e-ISSN 2620-9292 


\section{PENDAHULUAN}

Sejak adanya pandemi penyakit menular yang disebabkan oleh Virus Corona atau Covid-19 di Indonesia, Pemerintah menghimbau agar pusat-pusat keramaian di hentikan sementara termasuk sekolah. Dampaknya, kegiatan belajar mengajar di sekolahpun terhenti. Kegiatan Belajar Mengajar di lanjutkan di rumah masing-masing atau biasa di sebut dengan BDR (Belajar Dari Rumah). Agar kegiatan tersebut berjalan dengan lancar maka pembelajaran dilakukan secara daring.

Berdasarkan hal tersebut, maka guru dituntut untuk terampil dalam menggunakan TIK agar proses belajar daring berjalan lancar. Namun, banyak guru yang mengeluh kesulitan memberikan pembelajaran daring, nilai siswa yang di bawah KKM menjadi masalah tersendiri bagi guru, karena itu berarrti guru belum berhasil dalam melakukan pembelajaran secara daring. Guru belum bisa memanfaatkan media pembelajaran daring secara optimal. Selain itu, guru juga belum bisa menerapkan model pembelajaran yang bisa menciptakan suasana pembelajaran yang menyenangkan, suasana pembelajaran yang lebih bermakna yang memungkinkan siswa untuk bisa menyerap materi-materi yang mereka pelajari tanpa beban, tanpa merasa kesulitan dan merasa bosan tentunya.

Dari berbagai persoalan di atas, maka sangat penting bagi guru untuk melakukan suatu inovasi dalam pembelajaran. Salah satunya adalah dengan merubah cara mengajar guru dengan model pembelajaran yang lebih efektif dan memungkinkan siswa belajar secara optimal sehingga pembelajaran tidak bersifat konvensional lagi tapi pembelajaran yang menempatkan siswa sebagai center dalam proses pembelajaran (student center).

Model pembelajaran dapat dijadikan pola pilihan, artinya para guru boleh memilih model pembelajaran yang sesuai dan efisien untuk mencapai tujuan pendidikannya (Rusman, 2013: 133). Menurut Zubaedi (2012: 185) model pembelajaran dapat diartikan pula sebagai pola yang digunakan untuk penyusunan kurikulum, mengatur materi, dan member petunjuk bagi guru dikelas. Pemilihan model pembelajaran akan mendukung hasil pembelajaran yang akan dicapai (Nugroho, 2020).

Hasil belajar menurut Maher (Yanuarti dan Sobandi: 2016) menjadi suatu pengalaman belajar bagi siswa dalam perubahan tingkah laku mereka dan hasil belajar tidak menjadi patokan bagi siswa untuk belajar lebih giat. Menurut Suprijono (2011: 5), hasil belajar adalah pola-pola perbuatan, nilai-nilai, pengertian-pengertian, sikap-sikap, apresiasi, dan keterampilan. Hasil belajar adalah suatu penilaian akhir dari proses dan pengenalan yang telah dilakukan berulang-ulang serta akan tersimpan dalam jangka waktu lama atau bahkan tidak akan hilang selama-lamanya karena hasil belajar turut serta dalam membentuk pribadi individu yang selalu ingin mencapai hasil yang lebih baik lagi sehingga akan merubah cara berpikir serta menghasilkan perilaku kerja yang lebih baik (Sjukur: 2020). Faktor yang mempengaruhi hasil belajar digolongkan menjadi tiga golongan yaitu faktor psikis, fisik dan nasib (Anas, 2016), sedangkan menurut Jusmawati \& Fitriana HS (2019), faktor yang mempengaruhi belajar siswa terdiri dari dua yaitu faktor internal dan faktor ekternal. Faktor internal meliputi faktor jasmaniah, faktor psikologis, dan faktor kelelahan, untuk faktor ekternal terdiri dari faktor keluarga, faktor sekolah, dan faktor masyarakat.

Salah satu model pembelajaran yang dapat ditawarkan adalah model pembelajaran Quantum Teaching. Kata Quantum memiliki arti interaksi yang mengubah energi menjadi cahaya. Quantum Teaching menciptakan lingkungan belajar yang efektif dengan menggunakan unsur yang ada pada siswa dan lingkungan belajarnya melalui interaksi yang terjadi di dalam kelas (A'la, 2010:21). Rusman (Nursalam, dkk: 2021) menyampaikan bahwa kerangka pembelajaran Model Quantum Teachingsering disebut sebagai TANDUR yaitu singkatan dari kata Tumbuhkan, 
Alami, Namai, Demonstrasikan, Ulangi, dan Rayakan. Kerangka pembelajaran ini dapat membuat siswa menjadi senang dan lebih tertarik pada suatu pelajaran dan dapat juga memastikan bahwa siswa mengalami proses pembelajaran diantaranya berlatih dan menjadikan isi pelajaran nyata bagi siswa itu sendiri. Quantum Teaching adalah pengubahan belajar yang meriah, serta menyertakan segala kaitan, interaksi dan perbedaan yang memaksimalkan momen belajar (Riyanto, 2010: 199). Quantum Teaching adalah panduan praktis dalam mengajar yang berusaha mengakomodasi setiap bakat siswa atau dapat menjangkau setiap siswa (Collin Rose, dalam Fathurrohman, 2015:179).

Berkenaan dengan hal tersebut, maka salah satu model pembelajaran yang dipilih dan diterapkan oleh peneliti adalah model pembelajaran Quantum Teaching. Menurut Sudiana (Fitria,dkk: 2019) menyatakan bahwa dalam rangka pengembangan profesional, guru tidak bisa melepaskan dirinya dari kegiatan akademik penelitian. Penelitian yang terkait langsung dengan tugas pokok dan fungsinya serta berdampak langsung terhadap peningkatan kualitas pembelajaran adalah Penelitian Tindakan Kelas. PTK dapat memberikan nilai tambah dan masukan dengan tujuan perbaikan mutu dan kualitas pendidikan di kelas/sekolah (Mulia dan Suwarno: 2016). Susilowati (2018) Penelitian Tindakan Kelas (PTK) juga dapat menjembatani kesenjangan antara teori dan praktik pendidikan. Hal ini terjadi karena kegiatan tersebut dilaksanakan sendiri, di kelas sendiri dengan melibatkan siswa sendiri, melalui sebuah tindakan yang direncanakan, dilaksanakan, evaluasi, dan refleksi. Dengan demikian diperolah umpan balik yang sistematik mengenai apa yang selama ini dilakukan dalam kegiatan belajar mengajar untuk diterapkan dengan baik di kelas yang ditekuninya. Jika sekiranya ada teori yang tidak cocok dengan kondisi di kelasnya. Melalui PTK, pendidik dapat mengadaptasikan teori lain untuk kepentinngan proses dan atau produk belajar yang lebih efektif, optimal, dan fungsional.

\section{METODE}

Subjek penelitian ini adalah siswa kelas V SD Negeri 1 Mewek, Kalimanah, Purbalingga, tahun pelajaran 2020/2021 semester 1 (gasal) yang berjumlah 17 siswa terdiri dari 12 siswa laki-laki dan 5 siswa perempuan. Penelitian ini dilaksanakan di SD Negeri 1 Mewek Kelas V secara daring melalui platform zoom meeting dan google classroom. Penelitian ini dilaksanakan secara bertahap pada bulan November 2020, pada semester 1 tahun pelajaran 2020/2021. Penelitian ini dilaksanakan menggunakan 2 siklus. Tiap siklusnya terdiri dari perencanaan, pelaksanaan, pengamatan, dan refleksi.

Pada tahap perencanaan dilakukan pengamatan pada proses pembelajaran daring, wawancara dengan orang tua siswa tentang masalah yang terjadi selama pembelajaran daring di era pandemi ini. Kemudian mengidentifikasi permasalahan pokok kemudian menyusun hipotesis untuk pemecahan masalah. Proses selanjutnya yaitu penetapan penerapan model pembelajaran Quantum Teaching dalam pembelajaran Tema 4 Sub Tema 2 yang diharapkan dapat memperbaiki dan meningkatkan hasil belajar siswa. Lalu guru menentukan kriteria keberhasilan penelitian. Setelah itu dilakukan analisis KI dan KD yang akan di gunakan dalam penelitian, memilih materi pokok yang akan diajarkan dan mengembangkan materi tersebut. Guru kemudian memilih metode yang akan digunakan sebagai pendukung dalam proses pembelajaran. Selanjutnya menyusun RPP yang mengacu pada model pembelajaran Quantum Teaching pada Kelas V Tema 4 Sub Tema 2 serta mempersiapkan sumber belajar, bahan materi, media, dan alat bantu yang diperlukan dalam pembelajaran termasuk memilih platform apa yang akan digunakan, LKPD, Lembar observasi, dan menyusun soal evaluasi.

Pada tahap pelaksanaan, guru menumbuhkan minat dan motivasi belajar siswa Kemudian guru memberikan apersepsi yang berkaitan dengan materi yang akan 
dipelajari dan memberikan kesadaran pada siswa mengenai manfaat mempelajari materi tersebut. Selanjutnya siswa dibagi menjadi beberapa kelompok, kemudian masing-masing kelompok membuat yel-yel sebagai motivasi mereka, setelah itu mereka diberi tugas untuk melakukan sebuah proyek berkaitan dengan materi yang di pelajari. Siswa menuliskan hal-hal penting dari materi yang telah mereka pelajari. Siswa menuliskan hal-hal penting dari materi yang telah mereka pelajari. Siswa bersama-sama merangkum kembali apa yang telah mereka pelajari dengan bimbingan guru. Guru bersama siswa merayakan keberhasilan mereka dalam pembelajaran dan menjawab pertanyaan-pertanyaan dengan meneriakan yel-yel. Kegiatan pembelajaran diakhiri dengan evaluasi hasil belajar dan pemberian tugas rumah menggunakan google form.

Tahapan berikutnya adalah pengamatan. Pada tahap ini, kegiatan guru dan siswa selama proses pembelajaran dengan menggunakan model pembelajaran Quantum Teaching diamati oleh observer dengan menggunakan lembar observasi yang telah di buat oleh peneliti sebelumnya.

Tahap terakhir adalah refleksi. Pada tahap ini, setelah diperoleh informasi dari hasil belajar siswa dan segala aktivitas guru dan siswa selama proses pembelajaran, di analisis dan di evaluasi apakah sudah mencapai tujuan dari penelitian atau belum. Jika tujuan belum tercapai maka dicari permasalahan yang belum tercapai untuk selanjutnya dijadikan sebagai bahan perbaikan pada siklus ke II.

\section{HASIL DAN PEMBAHASAN}

Penelitian ini dilakukan dalam dua siklus dengan menggunakan model penelitian tindakan kelas menurut Suharsimi Arikunto. Tiap siklusnya terdiri dari 1 kali pertemuan. Pengamatan terhadap hasil belajar siswa terangkum dan disajikan pada gambar berikut ini.

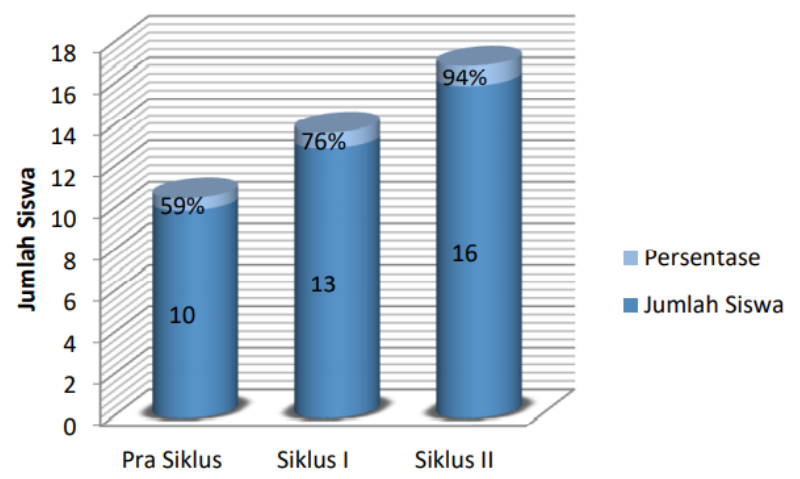

Gambar 1. Diagram Peningkatan Jumlah Siswa yang Telah Mencapai KKM

Berdasarkan analisis data di atas dapat dilihat bahwa ada kenaikan dari pra siklus ke siklus I dan dari siklus I ke siklus II. Untuk nilai hasil belajar, sebelum dilakukan penelitian tindakan dengan model Quantum Teaching, diperoleh data nilai dengan rata-rata kelas 5689 sedangkan siswa yang sudah mencapai KKM $\geq 70$ sebesar 59\% (10 siswa dari 17 siswa) kemudian pada siklus I menjadi 76\% (13 siswa dari 17 siswa) dengan nilai rata-rata kelas sebesar 79. Sebenarnya untuk siklus I nilai rata-rata yang diperoleh siswa sudah mengalami kenaikan dari sebelum dilakukan tindakan namun karena belum mencapai persentase keberhasilan yang telah ditetapkan peneliti sebelumnya, yaitu belum mencapai $80 \%$ yang mencapai KKM, maka penelitian perlu dilanjutkan pada siklus II dengan melihat catatan-catatan penting yang masih perlu direfleksikan lagi untuk perbaikan pada proses pembelajaran berikutnya. Pada siklus II juga mengalami kenaikan, yaitu nilai rata-rata kelas naik 
menjadi 82 dan siswa yang sudah mencapai KKM $\geq 70$ naik menjadi $94 \%$ (16 siswa dari 17 siswa). Dengan demikian, hasil belajar pada siklus II dapat dikatakan telah mencapai indikator keberhasilan penelitian yang telah ditetapkan sebelumnya, yaitu sebesar $80 \%$ siswa telah mencapai $\mathrm{KKM} \geq 70$ dan untuk 1 siswa yang belum mencapai KKM akan dilakukan remedial.

\section{SIMPULAN}

Berdasarkan data yang telah diperoleh dalam penelitian ini, dapat disimpulkan bahwa model pembelajaran Quantum Teaching dapat meningkatkan hasil belajar siswa kelas V SD Negeri 1 Mewek, Kalimanah, Purbalingga. Hasil penelitian menunjukkan adanya peningkatan hasil belajar siswa dari pra siklus sampai dengan siklus II. Pada pra siklus, nilai rata-rata hasil belajar siswa adalah 56 dan siswa yang mencapai KKM baru 59\% dari 17 siswa, kemudian pada siklus I nilai rata-rata hasil belajar siswa meningkat menjadi 79 dan siswa yang mencapai KKM sebesar $76 \%$ dari 17 siswa. Pada siklus II juga mengalami peningkatan, yaitu nilai rata-rata hasil belajar siswa menjadi 82 dan siswa yang mencapai KKM sebesar 94\% dari 17 siswa.

\section{DAFTAR PUSTAKA}

Anas, S. (2016). Pengantar Evaluasi Pendidikan. Jakarta: Raja Grafindo.

A'la, Miftahul. 2010. Quantum Teaching Melejitkan Potensi Guru-Murid Seoptimal Mungkin. Diva Press : Yogyakarta

Fathurrohman, Muhammad. (2015). Model-Model Pembelajaran Inovatif. Jogjakarta: Ar-Ruz Media.

Fitria, Happy, dkk. (2019). Upaya Meningkatkan Kompetensi Guru Melalui Pelatihan Penelitian Tindakan Kelas. Abdimas Unwahas, Vol.4, No.1. Retrieved from https://publikasiilmiah.unwahas.ac.id/index.php/ABD/article/viewFile/2690/2651

Fitriana HS, E. (2014). Komparasi Keefektifan Model Pembelajaran Kooperatif Tipe Make A Match dan Pengajaran Langsung dengan Pedekatan Saintifik dalam Pembelajaran Matematika Materi Lingkaran pada siswa Kelas VIII SMP Ummul Mukminin Makassar. Program Pascasarjana Universitas Negeri Makassar.

Mulia, Dini, Siswani dan Suwarno. (2016). PTK (Penelitian Tindakan Kelas) Dengan Pembelajaran Berbasis Kearifan Lokal dan Penulisan Artikel IImiah di SD Negeri Kalisube Banyumas. Khazanah Pendidikan: Jurnal IImiah Kependidikan, Vol. IX, No. 2. Retrieved from

http://jurnalnasional.ump.ac.id/index.php/khazanah/article/view/1062

Nugroho, Wahyu,A. (2020). Improved Learning Outcomes of Natural Science Lessons Through Google Meet Assisted Project Based Learning (PjBL) Learning Models. sHEs: Conference Series 3 (3). 215 - 220. Retrieved from https://jurnal.uns.ac.id/SHES/article/view/45835/28803

Nursalam,Muhammad, dkk. (2021). Efektifitas Model Quantum Teaching Terhadap Pembelajaran Matematika Siswa di Sekolah Dasar. Jurnal Basicedu Vol 5 No 2. Retrieced from http://jbasic.org/index.php/basicedu/article/view/724/pdf

Riyanto, Yatim. (2010). Paradigma Baru Pembelajaran. Jakarta : Prenada Media.

Rusman. (2013) Model-Model Pembelajaran: Mengembangkan Profesionalisme Guru ed 2, Jakarta : Rajawali Pers

Sjukur, Sulihin, B. (2012) Pengaruh Blanded Learning Terhadap Motivasi Belajar dan Hasil Belajar Siswa Tingkat SMK. Jurnal Pendidikan Vokasi. Vol 2, No.3. Retrieved from https://journal.uny.ac.id/index.php/jpv/article/view/1043/844

Suprijono, Agus. (2011). Cooperative Learning Teori dan Aplikasi PAIKEM. Yogyakarta: Pustaka Pelajar 
Susilowati, Dwi. (2018). Penelitian Tindakan Kelas (PTK) Solusi Alternatif Problematika Pembelajaran. Edunomika-Vol.02, No.01. Retrieved from https://jurnal.stieaas.ac.id/index.php/jie/article/view/175/138

Yuniarti, Ari dan A. Sobandi. (2016). Upaya Meningkatkan Hasil Belajar Siswa Melalui Penerapan Model Pembelajaran Quantum Teaching. Jurnal Pendidikan Manajemen Perkantoran, Vol. 1 No. 1, Agustus 2016, Hal. 11-18. Retrieved from https://ejournal.upi.edu/index.php/jpmanper/article/view/3261/2313

Zubaedi. (2012) Desain Pendidikan Karakter, Konsepsi dan Aplikasinya dalam Lembaga Pendidikan, Jakarta: Kencana 